\title{
4. The Boakaine Mine in New Caledonia: A Local Development Issue?
}

CHRISTINE DEMMER

\section{Introduction}

Following several years of severe tension between Kanak separatists on one hand, and the French state and descendants of the colonists on the other, the Matignon-Oudinot Agreements, which were signed in June 1988 , brought peace to New Caledonia. Two of the three provinces established at that time-North Province and Islands Province-have since been administered by the separatists. They set themselves the objective of developing these areas, which are populated mainly by Kanaks and had previously been considerably less affluent than South Province, which includes the capital Nouméa and is home to the bulk of the white population. However, the acceptance of these agreements by the Kanak nationalists from the Front de Libération Nationale Kanak Socialiste (FLNKS), and the associated concept of 'economic rebalancing', only made sense to them in the context of what remains their ultimate objective- the achievement of independence.

Naturally, nickel was the abundant resource that the elected representatives of North Province immediately tried to develop for this purpose. In 1990, the FLNKS established an entity called the Société 
de Financement et d'Investissement de la Province Nord (SOFINOR), an ad hoc finance and investment vehicle that immediately purchased the mining company Société Minière du Sud Pacifique (SMSP), which was formerly a subcontractor of New Caledonia's oldest nickel mining company, Société Le Nickel (SLN). After 20 years of management by the separatists, SMSP had become a holding company that was no longer directly involved in the mining of nickel ore, but instead financed and developed a number of industrial and metal-processing projects. Since 1995, it has been the world's primary exporter of nickel and holds 51 per cent of the shares in the companies it manages in partnership with the Swiss company Glencore (formerly Xstrata), the South Korean company POSCO, and the Chinese company Jinchuan (see Chapters 2 and 3, this volume). Through these arrangements, it provides revenues to North Province via SOFINOR, which holds 87 per cent of the company's shares, and contributes to the establishment of other companies and also to the development of the local tourist industry and economic infrastructure.

The focus of this chapter is a sequence of political events surrounding the forced closure of one nickel mining operation in the Kanak municipality of Canala in 2002. Canala is located on the east coast of North Province, adjacent to the border with South Province (see Figure 2.1, Chapter 2). In 2009, its resident population was more than 3,300, and its territory hosted four major colonial chieftaincies (chefferies): Bwaaxéa, Kèrèduru, Nôôme and Penyîmê Nèkètè (or Nakéty). This municipality found itself in a strong position in the new economic and political system because it contained three major nickel deposits-Nakéty, Bogota and Boakainethat had been mined since the late nineteenth century, and accounted for 25 per cent of New Caledonian nickel reserves in 2000 (Boisard 2002).

The exploitation of these deposits was in some ways symbolic of the new direction adopted by the separatist struggle. Indeed, Canala was selected as the location of the discussions held in August 1989 that led to the purchase of SMSP by North Province. These discussions were held in the wake of the Ouvéa Cave hostage crisis of May 1988, when 19 Kanak hostage-takers died in an operation mounted to express their opposition to proposals made by Bernard Pons, then Minister for Overseas Departments and Territories, during the course of a French presidential election. The new minister, Louis Le Pensec, accompanied Prime Minister Michel Rocard in this new round of discussions. 
The French politicians clearly chose Canala as the site of these discussions because it was home to some of the key actors in les événements of 1984. These 'events' had included the active boycott of the legislative elections held in that year, as well as blockades, land occupations and expulsions of colonial settlers. They visited the municipality, which was home to the separatist leader Eloi Machoro, the former general secretary of the separatist party Union Calédonienne. They also visited the traditional lands of Léopold Jorédié, a member of the same party, who became one of the leaders of the FLNKS after Machoro was assassinated in 1985. Jorédié had recently been appointed as mayor of the municipality of Canala, and was elected as the first president of the newly established North Province, having previously been director of the North 'Region' that preceded it between 1985 and $1988 .{ }^{1}$

The message conveyed to the representatives of the French state by the separatists in August 1989 was quite clear: it was essential that they be given the resources necessary to develop their provinces and municipalities. The agricultural micro-projects that had been developed in preceding periods would no longer satisfy them. The acquisition of a mining company and mining concessions was far more in line with their economic and political demands.

Having won that argument, the new directors of SMSP purchased 22 concessions over the Boakaine deposit from SLN in 1991.2 Mining activity started in the following year, with local workers being recruited to participate in what was seen as part of the economic struggle for independence. However, ten years later, in 2002, the operation came to an abrupt end, despite the presence of extensive nickel reserves and its enormous symbolic resonance. The workforce was temporarily laid off after the suspension of the contract to supply a Japanese smelting company (PAMCO), ${ }^{3}$ and this event triggered a general strike and the ransacking of the site.

\footnotetext{
1 During that period, New Caledonia was divided into four 'regions'-North, Centre, South and Loyalty Islands.

2 In the local language, Xârâcùù, the name Bwakaiinè (Boakaine) is derived from the words bwa ('head'), kaii ('light up'), and nè ('fire'). This name alludes to the torch-lit processions that were held on the range and previously marked the opening of the yam harvest festival. Boakaine was the site of one of the very first concessions in the Grande Terre to be mined by a colonial settler (in 1874), and he was also one of the founders of SLN (in 1880). Like Nakéty, it has been more or less intensively mined at different periods since then.

3 This was before SMSP established a new partnership with the Korean company POSCO.
} 
Difficult working conditions, inadequate salaries and safety problems were cited by the local branch of a trade union as justifications for these actions. However, another kind of argument opened with a reading of the conflict in terms of the relationship between social classes. Furthermore, customary leaders (coutumiers) who embodied the Kanak political order also reminded people that SMSP had failed to keep promises made when the mine was opened. These involved the progressive handover of mining concessions or-at the very least—of operational control to the local population.

Despite the relaunch of negotiations between SMSP and local actors in recent years, the situation was not resolved in the decade following this strike. Attempts were made to establish an operating company whose shares would be held by the local clans, but the municipal authorities insisted that they should be the primary local partners of SMSP because of their responsibility for local economic development. So was this really a conflict between two legitimate political authorities-the elected municipal (and provincial) separatist leaders on one side, opposed by customary leaders from the four big chieftaincies on the other side?

In my attempt to answer this question, I adopt an approach from political anthropology that sets out to describe how colonised and formerly stateless, segmentary societies currently deal with the problem of segmentation. 'Segmentary societies' are here understood to be those in which the 'political system' consisted of groups organised by models of kinship (clans, lineages, etc.), whether or not they were headed by 'chiefs'. In New Caledonia, chieftaincies have been associated with specific territories (reserves) and organised into 'tribes' (tribus) and customary 'districts' since the early colonial period, with the former headed by 'small chiefs' and the latter by 'big chiefs'. ${ }^{4}$ The representative bodies are the 'council of elders' (now known as the 'council of the clan chiefs') at the tribal level, and the (customary) 'district council' at the level of the municipality. The district council comprises the big and small chiefs within the district, plus any presidents of the tribal councils who are not chiefs in their own right, and it elects its own president. The occupants of these various positions are all

4 Reference to the big chieftaincies as separate 'districts' is avoided in the rest of this paper, since the term is also applied at a higher level, where the boundaries of the (customary) district are roughly aligned with those of the municipality. There is one small chieftaincy (Koh) that belongs to the neighbouring commune of Kouaoua but is part of the customary district of Canala. 
known as 'customary leaders' (coutumiers), but that term is also applied to the descendants of the first occupants of a place who may have ceded their authority to a 'stranger chief'. ${ }^{5}$

This is the context in which I explore the connections between two forms of legitimate authority (see Horowitz 2009). Does a conflict between them mean that 'imported' political legitimacy is never fully accepted, or that the prospect of economic benefits at a local level enables the reactivation of endogenous political legitimacy? My approach to this particular problem-which is based more broadly on an approach to social change in the colonial and post-colonial context-is in line with that of the so-called 'Manchester School', which was originally developed during the late colonial period in Southern Africa (Gluckman 1940a, 1940b, 1942; see also Chapters 1 and 5, this volume).

Beyond the event represented by the closure of the Boakaine mine, my analysis aims to contribute to an explanation of the current status of sociopolitical relationships in New Caledonia at different levels, especially at the municipal level. Given that chieftaincies were colonial spatial and political constructs intended to reflect the traditional form of Kanak political organisation, linked to the legal framework under which native reserves were established through the second half of the nineteenth century, ${ }^{6}$ the municipal space (and not the municipality as a formal body) should be considered as a hybrid unit of analysis compared to Western political models. I also propose to consider the place of the municipality within its provincial context and, beyond this, in the context of an 'overseas state' that is still formally part of the French state but also in the throes of an already advanced movement towards independence. However, unlike Gluckman, who approached the political situation of the Zulu people in Zululand through a detailed account of the changing relationships between 'colour groups' in the South African state, the situation I describe involves relationships between groups of Kanaks. This certainly applies at the level of the relationship between the municipal authority and the chieftaincies of Canala, from which the last colonial settlers were expelled during les événements of 1984, but also applies with respect to the relationship between the mining company and the 'local populations' at the provincial

5 In Canala, people in this latter category are known as 'great subjects' (kwara aéé).

6 Reserved lands were decreed as inalienable (see Merle 2000). Since 1998, they have become 'customary lands' as part of the process of negotiated decolonisation, and are still not subject to the common law. 
level. Accordingly, I not only take account of the effects of historical legacies and/or the reactions to foreign domination in my analysis of this intra-Kanak political game; I also consider, in particular, the question of the historical depth of Kanak participation in the territory's political life since the 1950s, which makes them 'political actors' in a double sense (see Soriano 2013).

The current political context includes Kanak control of the provincial authorities (in two provinces), which has been seen as a springboard for the recovery of a sovereignty that has yet to be attained. The Boakaine conflict can only be fully understood against the backdrop of this very specific transitional context. From the perspective of the Kanaks, this is primarily what positions the operation of this mine-and the whole of SMSP - at the interface between an economic and political issue. And this is what also results when competition for responsibility for local development based on the mining industry can set different political levels or figures against each other, even though the Kanak political parties regard this development as a contemporary objective in their struggle for independence.

\section{A Conflict Between Separatist Parties}

In reality, an understanding of this conflict during the period before the mine was closed must go beyond the question of how Kanak actors have mobilised and prioritised the different sociopolitical repertoires available in a competition for control of the nickel economy. It depends more broadly on an understanding of Kanak involvement in the process of decolonisation, which in turn involves consideration of the relationship between traditional political legitimacy and partisan political struggles. When the mine was reopened in 1991, the future protagonists in the strike of 2002 presented themselves as separatists, not as customary leaders, and were proud to show that their party, the Union Calédonienne (UC), was strongly positioned as an actor involved in the new strategy that was adopted in the pursuit of political power. Gaetan Dowadé, who was Jorédié's 'right-hand man' and deputy mayor in Canala at that time, explained this to me as follows:

At that time [in 1991], we took SMSP. Léo [Jorédié] said to me: 'Set up a company in Canala, get the people together, we will see how we shall set about reopening Boakaine. We will take SMSP. We will see which mine will be opened after that.' That's when I knew that Jean Marie [Tjibaou] 
presented proposals to [Jacques] Lafleur ... for the repurchase of SMSP. So each municipality had to set up a municipal mining company. We would set the example. The miners set up there before, and they didn't ask [permission] for anything. After the 'events', they had to go through us. (personal communication, Gaetan Dowadé, 26 July 2011)

Like other statements of the same nature, this quote from an interview leaves no doubt as to the capacity of the municipality's militants to fulfil the objectives of the FLNKS by themselves. They shared, and indeed were among the initiators of, the vision of development through the mining sector that was known as 'the vision for the country', and was to be realised at the level of North Province in anticipation of the recovery of national sovereignty. This was not a vision that set the indigenous and nonindigenous communities in opposition to each other, like the one that proposed to capture the mining revenues at the level of what were referred to in the 2000s as the 'mining chieftaincies' (Demmer 2007). Instead, to identify the logic of this conflict, it is necessary to look beyond a claim based purely on political identity, as represented in the argument that 'the chieftaincies should be able to assume responsibility for development'. One must also consider the reference to customary political institutions as one that was made to serve ends other than the simple defence of a certain kind of sub-national political legitimacy. ${ }^{7}$ In the present case, the explanation may perhaps be found in the particular-and sometimes tense-relationship between the municipality of Canala and North Province after the mine had been reopened in 1991.

As already mentioned, Léopold Jorédié was not only a native of Canala, but in 1989 he was both the mayor of this municipality and the first president of North Province. However, as an elected representative of the UC, he lost both of the mandates he had acquired in 1989-first at the municipal level in 1995, and then at the provincial level in 1999. In 1998, shortly before the signing of the Nouméa Agreement, Jorédié wanted to negotiate directly with the loyalists without being bound by the 'mining prerequisite' that stipulated construction of a nickel processing plant in North Province (see Chapter 5, this volume). Supported by François Burck, another elected representative of the UC, and Raphaël Mapou, representing the Parti de Libération Kanak (PALIKA),

7 Incidentally, in the context of Kanak emancipation and involvement in the nickel economy, my remarks highlight the extent to which an interpretation of actions taken to restrict control of natural resources in terms of the affirmation of indigenous people's rights cannot fully reflect the dynamics of political relationships between mining companies and local populations in New Caledonia. 
he therefore established a new coordinating body known as the Comite de Coordination des Indépendantistes, which subsequently became the Fédération des Comités de Coordination Indépendantistes (FCCI).

These developments in the political career of Jorédié-and above all his electoral disappointments-prompted several of my informants to claim that he was trying to get some of his supporters to launch a strike at Boakaine with a view to creating difficulties for PALIKA, which was then the dominant party in the province, which was in turn the main shareholder in SMSP via SOFINOR. Given that he could not aspire to take control of the company again, this was a way of dealing a severe blow to a party that had achieved a leading role in the attainment of the new political and economic objectives established by the FLNKS, for it was the UC that had been able to take credit for this achievement in the late 1980s. In the words of Jorédiés chief lieutenant, recalling the reopening of the mine in 1991:

We became indispensable on the level of the mine. I speak of us, the UC, the strongest people in Canala. It will be said ... you have to go through the FLNKS. But we were UC FLNKS.

Removed from power in both politics and business, Jorédié would then attempt to damage SMSP and the party that controlled the province, both of which were heavily reliant on the Boakaine mine to supply the nickel required by their new Korean business partners.

Viewed in this way, the conflict is very specific - rooted as it is in the micro-political history of North Province-but also highly personalised. Accordingly, it will come as no surprise to learn that no other mine owned by SMSP experienced a conflict as serious as this one. Even if the supporters of parties other than PALIKA worked in the mines or were leaders of the municipalities or chieftaincies that hosted the mine sites, there was no situation like that which emerged in Canala, where the mayor who had represented the municipality had also been president of the province during negotiations over the role of mineral resource development in the struggle for independence.

However, it is necessary to go further in the analysis of this conflict, for it did not merely involve the settlement of a personal account by a politician whose political career was in decline. Examination of the facts leaves no room for doubt that the leaders of the strike that led to the closure of the mine were in the FCCI camp. Apart from the blow dealt to their 
political opponents, the leaders of the strike clearly intended to position themselves as new partners in dialogue with SMSP, either in the short or medium term. It is in part the same people, the former leaders of the FCCI (which no longer exists), ${ }^{8}$ who proposed in 2011 to establish a clan-based company in Canala to manage the mine. One informant summarised the point as follows:

There was a political concern because Léo [Jorédié] belonged to the UC and the UC started the struggle, and he wanted to reassume control of Boakaine as a source of financial support for his party.

But beyond the question of party finance suggested by this informant, the conflict offers manifest evidence of the centrality of the issue of control over the mines for all the separatist parties, first from the time of the Matignon-Oudinot Agreements in 1988, and even more so from the time of the Bercy Agreement that contained the 'mining prerequisite' to the Nouméa Agreement of 1998.

In this regard, the logic of this strike-if not all of its immediate pretextsis liable to recur in the party political relationships found in all the mining municipalities. What is at stake today for each of the separatist parties is the need to demonstrate their capacity to respond to the current demands of the struggle: being the actors who know how to mine nickel means being those who are closest to the logic of decolonisation as this has been defined for almost 25 years. This contrasts with the earlier period of the 'regions', when micro-development projects to 'build Kanaky' flourished, and many Kanak political actors were mainly concerned to promote the interests of their own party at a purely local level (Demmer 2016). The exercise of party political control over nickel mining has proven to be a means of winning points in the struggle for power at all levels of political organisation.

In the majority of cases, it would also be a mistake to simply interpret the attempts of Kanak political parties to access mineral revenues in terms of a quest for limited economic benefits. Although it is not possible to rule out such motives completely, it remains crucial to keep in mind the centrality

8 Support for the FCCI waned after 2004, although Jorédié (who died in September 2013) organised a list of candidates for the North Province elections in 2009. Today, his right-hand man in Canala, Gaetan Dowadé, is an active member of Parti Travailliste. 
of mining issues for the separatists, in the context of decolonisation, in order to understand the ideological logic that has governed these 'rentseeking' practices.

There is another kind of economic logic that could help to explain the appearance of ultra-local development claims originating from political entities as varied as clans, chieftaincies, municipalities and newly defined 'customary areas'. ${ }^{9}$ There are no tax revenues from the operation of nickel mines that are allocated to local public expenditures. The creation (in 2009) of a 'nickel fund' that is supposed to be financed from corporate income taxes and to pay for various forms of social insurance and environmental remediation in the mining sector is the only existing tax mechanism with direct local impact. ${ }^{10}$ These claims have their roots in the deeper problem of redistributing the wealth arising from the exploitation of the country's primary natural resource.

This leads me to highlight an additional aspect of the political party contest over Boakaine. The elected representatives of Canala see themselves as being positioned at the end or bottom of the SOFINOR aid chain. As one of them put it:

SOFINOR! It took money from Boakaine and invested it in other structures. You should see the organisation chart for SOFINOR. There are plenty of subsidiaries but none in Canala, not for development or anything else!

Although I was unable to verify this particular allegation, the issue is one of concern to both the elected representatives and ordinary people of Canala. Moreover, the concern grew with the change in the province's ruling majority, since Canala is one of the historical fiefdoms of the first political party that attracted popular Kanak support. The chieftaincies of this district were evangelised by Père Luneau between 1920 and 1940, and it was he who established the Union des Indigènes Calédoniens Amis de la Liberté dans l'Ordre, which later became the UC. Many of the municipality's inhabitants have remained loyal to this party, and some

9 Each of the eight 'customary areas' includes a number of customary districts and chieftaincies. They were established under the Matignon-Oudinot Agreements, and are defined by a mixture of linguistic and political criteria.

10 New Caledonia has struggled to abandon a fiscal regime that grants special favours to the mining industry. Registered mining companies are entitled to almost complete exemption from taxes for 15 years after the point at which their actual production reaches a threshold of 80 per cent of a nominal target, with a 50 per cent exemption for the following five years. 
believe that this is the reason why it has suffered discrimination at the hands of the PALIKA representatives at the provincial level, who think of Canala as the municipality of Léopold Jorédié. Some informants thought that the municipality had problems in securing provincial support for its development priorities because it was particularly 'well served' in the earlier period when Jorédié was the president, so this either represented the 'fair' backswing of a partisan pendulum or a simple rebalancing between the municipalities in North Province over time.

My analysis of the conflict could conclude here if the question did not remain as to why the claim for control of Boakaine was initiated in 2002 by FCCI members and supporters, but increasingly passed to the municipality's chieftaincies. It is not only the big chieftaincies but the small chieftaincies of Mèèwèè (Méhoué), Bwakaiinè (Boakaine), Nôôwé (Nonhoué) and Mèrènèmè (Mérénémé), which have the strongest territorial links to the nickel deposits, that claim the mine for themselves. This insistence on the chieftaincies as legitimate beneficiaries is part of the contemporary debate about reopening the mine that has placed the municipality and the customary authorities in opposing positions.

\section{How the Militants Became Customary Leaders}

Following the purchase of the Boakaine mining concession in the wake of 'the events', Raphaël Pidjot, then a director of SMSP, and André Dang Van Nha (commonly known as André Dang), the company's chief executive officer, launched a series of local discussions about the participation of the people of Canala in its operation. It was explained to me that: 'The customary people of the municipality were always involved in the discussions ... It was said that the mine was a political and customary asset'. This discourse was easily sustained because the people who had been at the barricades in 1984 and 1988 included elected representatives of the municipality who were also customary leaders. However, what was mainly sustained in this process was the emergent belief of the separatists in a 'Kanak way' of organising production and establishing companies.

It was on this basis that the Compagnie Minière Kanak de Canala (COMIKA), the local partner of SMSP, was established in 1992 with capital amounting to one million francs. All of the tribus (small chieftaincies) within the municipality held shares in this company through 
different types of corporate entity-whether limited liability companies (sociétés à responsabilité limitée), 'economic interest groups' (groupements d'intérêt économique), or the hybrid entities known as 'local groups with special rights', groupements de droit particulier local (GDPLs). ${ }^{11}$ Together they held 20 per cent of the shares, while the remaining 80 per cent was held by SMSP.

The president of COMIKA was also the deputy mayor of Canala, so the municipal authority had close links with the tribus. His list of preferred candidates for the municipal election had been compiled through the selection of a candidate from among the leaders of each tribu. The economic ideal of the time was respected: the company involved segmentary groups and was identified as a communal structure.

COMIKA's dividends were supposed to be paid into an investment fund dedicated to municipal development, and distribution of this money was entrusted to the councils of elders. According to one informant: 'They wanted a bank like SOFINOR but just for Canala.' Economic rebalancing at the level of North Province presupposed development at the level of the mining municipalities, and it was they who were initially seen as having a legitimate interest in SOFINOR, the main shareholder of SMSP. In Canala, this could further consolidate the position of the UC and the municipal authority led by Jorédié.

According to my informants, COMIKA was dissolved in 1995. Officially, this was because SMSP pushed for its liquidation, having waited in vain for Canala's inhabitants to increase their level of investment. Its failure was said to have been hastened by management problems. This event also coincided with the victory of the Union Nationale pour l'Indépendance (UNI), an FLNKS coalition that included PALIKA but not the UC, in the municipal elections of that year. This was the point at which Léopold Jorédié lost his own seat.

Following the liquidation of COMIKA, SMSP established Boakaine Mining with a view to enlisting the mineworkers as shareholders in the mining operation. André Dang was the company's first president, and there

11 A GDPL is a legally recognised form of organisation, with a legal personality, that is meant to promote economic activities on customary land. It brings together individuals who are connected through customary bonds (within a family, clan or tribu). Thus the GDPL is primarily constituted of persons with customary civil status and is managed under customary law. It may also be used in the context of land claims. 
were five locally based directors_-Patrice Mwâsadi, Henri Suènô, Pwêêdi Chanel, Christian Onyiari and André Dowadé—who were 'nominated by the people of Canala'. Some of these men joined the FCCI when it was established in 1998, while others remained loyal to the UC. Boakaine Mining was liquidated in 2002 following the strike. Some people did not regard it as a municipal entity but simply as an SMSP subsidiary.

In 1998, Patrice Mwâsadi, who was the president of the council of elders of the Mèèwèè chieftaincy, and close to Jorédié, became the second president of Boakaine Mining. He is one of the kwara bwatù ('subjects who lower themselves'), which refers in this context to the members of a host clan who are supporters of a 'stranger chief'. However, he claims that he was accused of lacking customary legitimacy by others groups asserting competing claims over the deposit. On this latter score, he pointed out that the big chieftaincy of Bwaaxéa had not had its own big chief for some time, and he was not only representing his own (small) chieftaincy of Mèèwèe in his capacity as president of its council of elders, but also represented all of the municipality's tribus because Mèmèè is the seat of the big chieftaincy of Bwaaxéa, and Bwaaxéa is itself the most senior of the four big chieftaincies in Canala. ${ }^{12}$ Furthermore, since the chieftaincy of Nôố had only been separated from that of Mèèwèè in 1940, and that of Bwakaiinè had only been separated from that of Nôôe during the 1990s, he could also present himself as being, in a sense, the 'customary leader of Boakaine'. Mwâsadi explained his position as follows:

There was a political [and] customary line: Mèèwèè and Gélima (Xürüchaa) were the two recognised tribal entities. In relation to the Boakaine mine: it was Mèèwè. There was a huge consensus on the nomination [of the board of Boakaine Mining]: Suènô is from Gélima, Pwêêdi Chanel is the chief of Mîâ/Xwinnè, and Dowadé is the president of the council of Mèrènèmè/Kakö. Onyiari was the jack-of-all-trades of Mèèwèè. Myself, I came back from Australia, I spoke English. Within the organisation of the UC in Canala, I was below Léo. With Dowadé, I assisted Léo in the North Province. And on the level of Mèèwè̀, my clan was the most important clan of the chieftaincy. We are the kwara bwatu.

12 Most people agree with this last point. The Kèrèduru chieftaincy is said to be directly subordinate to Bwaaxéa, while Penyîmê Nèkètè is said to be subordinate to Nôôme, and Nôôme is ranked lower than Bwaaxéa. 
The other vehicle for dialogue between the mine's operators and the local population was the so-called 'recruitment committee', also known as the 'customary committee', which was established at the same time as COMIKA. This committee was composed of six persons who all had traditional links with the Boakaine deposit-two each from the tribus of Mèèwèè, Nôôwé/Bwakaiinè, and Kakö/Mèrènèmè (also part of the big chieftaincy of Bwaaxéa). They constituted the link between the mining operation and three of the four big chieftaincies of Canala. ${ }^{13}$ The committee members were paid about XPF18,000 each month for their attendance at two or three meetings with the mine's management to discuss local people's complaints (mainly on questions of pollution), and to find out what jobs needed to be filled and how current workers were performing. The chiefs and presidents of the council of elders of each tribu contacted by the committee then selected the local people who would fill any vacancies in the workforce. Each of the committee members paid XPF1,000 from their monthly stipend into a common fund intended to contribute to the purchase of a minibus for transporting the workers to and from their workplace. This payment was clearly requested by the committee members in exchange for maintaining social peace.

Prior to 1999 , this committee had also ensured that the trade unions did not gain a foothold in the mine. As its first president explained: 'We did not want this ... because we did not want to defend the lazy people. We fought to have this instrument, it was necessary for the people to work. ${ }^{14}$ It was in the context of the breakdown of the dialogue between the mining company and the 'local circle' of former UC members around Léopold Jorédié that the trade unions gained access to the mine in 1999. Given that the leadership of the municipal authority had by then passed to the UNI, and Boakaine Mining was under the control of individuals who had remained loyal to the UC, the FCCI members attempted to regain control in a different way. It was they who encouraged two trade unions, first the Union des Syndicates des Ouvriers et Employés de NouvelleCalédonie and then the Confédération Syndicale des Travailleurs de Nouvelle-Calédonie, to establish their presence at the mine site. It was the second of these unions that initiated the strike in 2001.

13 The big chieftaincy of Penyîmê Nèkètè (or Nakéty) was left out of this process because it has its own mining operations, and its inhabitants would prefer to work on these.

14 Much of the work involved filling the ore carriers for PAMCO (the Japanese foundry) as quickly as possible, and even working on Sundays due to the 'urgency of the economic rebalancing'. 
The discourse concerning the lack of recognition of the chieftaincies emerged at the same time. The strike led to the recollection of commitments supposedly made by André Dang to the customary leaders in the chieftaincy of Mèèwèe in 1991 that entailed greater participation of the chieftaincies in the actual operation of the mine. Some informants referred to a promise that operational responsibilities would be transferred to COMIKA or its successor, Boakaine Mining, after ten years—or even earlier. Other informants recalled a proposal to increase COMIKA's shares in the operating company to 51 per cent. Dang was also said to have promised that COMIKA would acquire ownership of the mine's vehicles-mainly trucks-and thus become a primary subcontractor. More peripherally, in the area of corporate social responsibility, he was supposed to have promised help for the renovation of a church and a bridge and the remediation of a former spa. Accordingly, the municipal authority had established an association through which revenues from the mine would be used to fund these projects, but this was wound up after the municipal elections of 1995.

Proposals to increase the level of customary shareholding in the mine were seemingly abandoned in 1995, since they were not supported by the majority of newly elected representatives who then assumed control of the municipal authority. They were raised again in 1998, when Patrice Mwâsadi became the president of Boakaine Mining, and then resurfaced in 2002 as a justification for the previous year's strike. While these demands made reference to local people's connection with the land, they were not based on a discourse of indigeneity that places colonised peoples in opposition to their colonisers, but rather on a 'localist' discourse that was less concerned with resistance to a form of external domination than with the reaffirmation of a political and genealogical history, even though some of Canala's clans could not claim that their ancestors had crossed the mineral tract of Boakaine at one time or another.

What was being demanded here was the recognition of a 'local' political authority based on the claim of some clans to precedence in the occupation of the land. This authority claims respect for those who were living in the environment of the mine, more than for those who accommodated the operators in a space to which they had distinctive rights based on their clan histories. From the way that the notion of 'respect' was invoked in my interviews, it became clear that this was a standard form of Kanak political logic — the logic of welcoming and hosting strangers according 
to specific rules and duties, and that this was the mindset within which COMIKA was established in 1992, albeit at the level of the municipality rather than the chieftaincy.

To understand the previous claim to ownership of the mining company, it is important to remember who was making it. The trade union leaders involved in the strike negotiated with the local leaders of the FCCI because the customary leaders who were most involved in the claim were also close to this party. The FCCI backed its claim by reference to the recognition of customary land rights in the Nouméa Agreement, and the former UC militants who moved to the FCCI thereafter presented themselves as customary leaders:

Before the split [between the UC and the FCCI] we worked to have the mine reopened. We, the former members of the UC municipal authority ... SMSP wanted to continue with us [FCCI] but we were outside the municipal authority. It [SMSP] preferred to continue to negotiate with us. It was they [the municipal authority] who blocked it. They wanted to erect a kind of barrier between us and Dang. They said: 'What happens at the mine is the municipal authority's problem! It is not the [problem of] the customary leaders.' Because we became customary leaders when we left the mine. They [the municipal authority] tried to separate us. But we were still working with the people there [in SMSP].

What this FCCI supporter is saying is that the status of 'customary leader' presented his group with an opportunity to reassert their rights after they had lost control of both the mine and the municipality (not to mention the province), so the former UC militants 'became customary leaders'. However, this was still a contentious designation, since the post-colonial segmentary logic that prevails in the customary domain meant that there were many different customary positions within the chieftaincies, partly originating in the structure of the colonial administration, which allowed for the assertion of competing claims. Therefore, conflicts between the directors of Boakaine Mining resulted in the emergence of a distinction between 'legitimate' and 'illegitimate' customary leaders, while those who claimed legitimacy in the context of their initial support for the FCCI closed ranks around the strikers and then wanted to be placed at the top of a clan-based shareholding company to recover control of the mine site.

Analysis of the first phase of the Boakaine conflict, up to the point of mine closure, provides a clear example of the instrumentalisation of the customary model of political organisation in a situation involving partisan 
political competition. Furthermore, rather than argue that a Western form of political legitimacy is unattainable in a segmentary form of political organisation, it would seem more reasonable to say that individuals accept the state and its local authorities as fully integrated institutional frameworks while not discounting other political models and institutions that may be mobilised in certain situations.

The virtual disappearance of the FCCI from the New Caledonian political landscape in the mid-2000s has altered the terms of more recent debates between the municipality, the 'customary leaders' and SMSP about the project of reopening the Boakaine. For the political parties, mining Boakaine is a matter of development from the perspective of independence, but it has also become an issue between the political figures authorised to represent development at that level. Former FCCI leaders initially argued for control of the mine to be located at the customary district level because its boundaries matched those of the municipality. In the new phase of debate about reopening the mine, the conflict is more definitively located in the debate supported by the indigenous movement, and reflects the recent evolution of the wider political debate in which the question of independence is superimposed on that of institutional pluralism (Demmer 2016).

In 2011, Martial Tyuienon, then president of the customary district of Canala, and acting as the official spokesperson for claims being made against SMSP, was still insisting that no one could claim ownership of the nickel ore. Only in 2014 did he begin to claim material or intellectual property rights in the mineral resource, echoing the claims made by various indigenous movements all over the world. In 2011 he said:

You can say you are the owner of the mining land. That's true. But not in relation to the nickel; you cannot know. We know who knows how to make yarn, grow taro, build houses, hunt animals, fish ... but did anyone burn stone to make iron?

During my fieldwork in 2014 he stated:

With help from family magic, even if they had no use for the nickel, my ancestors knew where to find it. They had the gift of seeing. They maybe knew about the nickel and used it for other purposes: yam and taro ... ${ }^{15}$

15 Martial Tyuienon died in 2016. 


\section{The Contest over Reopening the Mine}

Initially, in 2010, the council of the customary district of Canala, supported by Jorédiés former vice-mayor (and most loyal ally), Gaetan Dowadé, was attempting to create a clan-based joint venture in the form of a société par actions simplifiée (SAS) with a view to reopening the Boakaine mine. This local development strategy would have bypassed both the municipality and the tribal councils. The clans in question were represented by 'clan chiefs' who are legally recognised in legislation that became effective in January 2007. Based on the sums paid by each clan at the outset (between XPF50,000 and XPF500,000), it was envisaged that the board of the SAS would distribute some of the dividends based on an evaluation of the clans' needs, while reinvesting the rest in collective projects within their tribus (or small chieftaincies). In addition, these 'customary' shareholders, through the district council and its president, would assume the role of the former 'recruitment committee' by selecting people to work at the mine. Decontamination and afforestation measures would be implemented by the district's 'mining committee', which would charge an 8 per cent levy on contracts concluded between the SAS and SMSP. The tribus close to the mine would receive preferential treatment in these subcontracting arrangements.

While some of the former FCCI leaders may already have planned to establish a private company that would operate like a 'municipal bank', redistributing dividends among the clans rather than the tribus, the 'masterminds' of this more recent project appeared to want to turn the customary district council into an administrative body that would be a real alternative to the municipal authority. ${ }^{16}$ Apart from the 'mining committee', the district would have a 'training and education' committee, an 'environment committee', a 'social committee' and yet another committee devoted to 'customary affairs'. As far as the proponents of the 'clan-based company' were concerned, the Boakaine mine would act as a financial reservoir for the development of the district rather than the municipality of Canala. ${ }^{17}$ However, the policy model here was still

16 This idea gained currency with the publication (in 2014) of the Charte du Peuple Kanak (Kanak People's Charter), which inspired by of the discourse of indigenous people's rights.

17 Customary leaders in Canala sometimes say that they are ready to share power with the municipal and provincial authorities, but sometimes say that they want to take it away. In this respect, they have had some difficulty coming to terms with the definition of legal pluralism contained in the Kanak People's Charter. 
based on a 'segmented' conception of the general interest, in which the priority was not to serve the individual citizens who would be represented by the municipal authority, but to ensure the well-being of the clans through the elders who held power in the traditional political hierarchy (Demmer 2009).

This would conflict with the UC-run municipality's conception of development. As previously noted, when the UNI secured its majority in the municipal elections of 1995 , its assumption of responsibility for municipal development was combined with a challenge to the status of the recruitment committee 'because that is not the law and the mine is the domain of the state'. Instead, the party proposed to deal with mining issues through the municipal mining committee, albeit with participation by the president of the customary district council and the president of the larger 'customary area' to which the district belonged. When the UC regained control of the municipality in 2001, the mayor, Gilbert Tyuienon, complained about the lack of benefits derived from local mining operations. The following comment was made at the mayor's office:

In Nakéty, the country is given 19 billions of nickel per year. It should be the most beautiful and tranquil tribu ... but it is often in the news for bad reasons ... The people of Canala are tired of being forced to be nothing more than metal workers who borrow 17 or 20 million and pay $\mathrm{XPF} 350,000$ in instalments every month!

Such sentiments were linked to an expectation that the New Caledonian congress (the country's legislature) would enter into serious discussions about increasing the level of taxes imposed on the industry and redistributing the benefits to the municipalities according to the principle of equalisation (or derivation).

In the first half of the current decade, the municipality's own plans to reopen the Boakaine mine were made contingent on the assumption of majority (51 per cent) ownership of the operation by a joint venture (société par actions simplifiée) known as Société Anonyme d'Économie Mixte Locale de Canala (SAEML Canala). This had been established in 2010 to promote agricultural development in the area, and would henceforth be able to use mineral revenues to fund such activities. The customary leaders would be represented in this entity through four GDPLs (groupements de droit particulier local) —one for each of the municipality's four big chieftaincies. Their involvement was seen as both a matter of principle, 
allowing for a distinctively Kanak form of participation, and also as a way of allaying the latent tensions between the elected representatives and the customary leaders.

However, the proposed GDPLs were subject to criticism by the district council, as the advocate of the clans recognised by the 2007 law, on the grounds that they were 'superficial', 'disconnected from real history' and would not reflect the reality of the segmentary political system. Conversely, some of the people who opposed the new joint venture were equally sceptical of the legitimacy of the 'new' clans. As one of them put it:

The clan chiefs. That was done from the top down. It should be the other way around. That comes from the [Customary] Senate. ${ }^{18}$ The Senate is the form the French gave to this chamber. They thought of the French system. Suddenly, they subjugate from top to bottom. But it's not like that. The people made the clan chiefs without a single thought! None at all!

Accordingly, representatives of the municipal authority and the customary district each can regard themselves as the most legitimate political actors, and believe that they should therefore control the benefits generated by the operation of local mines. During this most recent period, each side has asserted the longevity of its own institutions. The elected representatives might talk about the 'immortality' of the municipality, or their own capacity to get things done, while the customary leaders might respond by stating a preference for consensus over the principle of universal suffrage, or complaining that elected leaders are too far removed from their 'roots'. Both sides also complain that the other cannot be trusted in the management of money. However, the customary leaders will sometimes admit that 'the municipality is the body that is closest to the population', while the elected representatives will say that they do not want to exclude the customary leaders who are part of the political landscape in all Kanak municipalities.

In this particular case, the elected representatives also wanted to keep their distance from the group of actors who were identified with the FCCI but had aligned themselves with the customary sphere. The municipality could therefore say that it had nothing against the customary leaders themselves but distrusted this particular group during the course of the

18 The Sénat Coutumier is an assembly of 16 senators, with two representing each of the eight customary areas. 
negotiations over the reopening of the mine. One Kanak businessman whom I interviewed did not even attempt to unravel these problems of identity and political legitimacy, but simply said that he understood the desire of the people living near a mine-whoever they were-to control the resource in the absence of a taxation system from which they derived any benefit (see Grochain and Poithily 2011).

A resolution was thus adopted in 2012, at a meeting held in in Mèèwèè, the 'headquarters' of the grand chieftaincy of Bwaaxéa, which stipulated that the customary leaders, the municipal authority and SMSP should all be involved in reopening the mine. For its part, SMSP understood the local people's desire to get control over the resource, especially in the absence of localised taxation, and wanted to encourage the creation of subcontracting companies, as well as local employment, training and shareholding. Although SMSP was unwilling to transfer the mining titles demanded by some of the customary leaders in Canala, it was prepared to negotiate a solution with local actors - whether customary leaders or elected representatives - who had not been party to the conflict of 2002 .

The elected representatives themselves decided to take a back seat in the negotiations in 2012. At the end of the day, no agreement was reached: the municipality has failed to hold discussions with the Boakaine tribus, while the district council still disagrees with the proposal to establish SAEML Canala, and SMSP is unwilling to transfer or farm out the mining titles to either the municipality or the district. The mine is still closed, and it will not reopen without a clear local agreement between the municipality and customary authorities and a negotiated arrangement between SMSP and the UC-led municipality. The first of these conditions seems more likely to be met, since the municipality is at odds with the UNI-run North Province over the redistribution of mining revenues and the support provided to Kanak private mining companies.

\section{Conclusion}

The conflict that led to the closure of Boakaine is a perfect entry point for understanding contemporary social relations in the Kanak world. In the context of the progressive decolonisation of New Caledonia, the conflict demonstrates the potency of this political issue for the pro-independence parties: they all see it as one that involves their status as leaders in the implementation of a project to prepare the economic grounds for 
independence. What this conflict also reveals is that the mines are tools of regional development for all political actors, both Kanaks and nonKanaks. Local development depends largely on SMSP, a company owned and controlled by North Province, and tensions emerge from the (feeling of a) lack of direct benefits at the municipal level, as has been explained in the case of Canala. Whereas the FLNKS thinks of resource management at the scale of the whole territory, the local redistribution of mining revenues at the local level remains a contentious issue-all the more so with the complex coexistence of elected and customary political entities.

The direct and indirect employment generated in and around a mine is not enough to meet local people's expectations on this score. In the era of neoliberal democracy, actors from the mining areas invite themselves to participate in the debate on this subject. Two closely related (though different) registers are mobilised in Canala. On one hand, people refer to a 'localist' legitimacy that reasserts the rights of 'the people from the place', meaning both the municipal residents and the subjects of the chieftaincies, or even the members of clans whose ancestors once traversed the mineral deposits. Due to the complex layering in the politics of recognition of Kanak customary entities since the colonial era, the definition of 'the place' can extend from the clan to the tribe, the district or even the customary area encompassing them. On the other hand, people adopt the most recent language of indigenous mobilisation, defending in a generic and well-structured manner the rights of the first occupants of a settler colony. This ethnocultural discourse asserts more clearly the ideological cleavage between elected representatives and customary authorities-the latter now seen as more legitimate bodies for the management of the mines and indigenous populations. The proximity of the referendum on selfdetermination can explain the flowering of this type of discourse as an alternative path towards decolonisation: the achievement of internal sovereignty through the legal recognition of cultural difference.

A change is worth noting here. In 2002, the need to consider customary areas, districts, chieftaincies and clans was expressed by Kanak politicians when they had lost their audience at a national or provincial level and tried to re-establish themselves at the local level. What is new here is that this strategy is not necessarily deployed to facilitate a return to electoral politics but that it still serves the political purposes of the customary actors themselves. Customary authority is invoked in its own right as an alternative form of power entitled to legal recognition. This evolution 
opens up avenues for the establishment of differentiated political rights, which would reconfigure once again the relations between Kanaks and non-Kanaks, as well as among the Kanaks themselves.

\section{References}

Boisard, M., 2002. Cartographie des Zones Dégradées dans la Région de Canala, Nouvelle Calédonie. Nouméa: Université Bordeaux 3, Institut EGID.

Demmer, C., 2007. 'Autochtonie, Nickel et Environnement en Nouvelle-Calédonie: Une Nouvelle Stratégie Kanake.' Vacarme 39: 43-48. doi.org/10.3917/vaca.039.0043

__, 2009. 'Secrets et Organisation Politique Kanake (NouvelleCalédonie): Pour Sortir des Catégories Privé/Public.' l'Homme (190): 79-104.

—_, 2016. Socialisme Kanak. Une Expérience Politique à Canala (Nouvelle-Calédonie). Paris: Karthala.

Gluckman, M., 1940a. 'Analysis of a Social Situation in Modern Zululand-A: The Social Organization of Modern Zululand.' Bantu Studies 14(1): 1-29. doi.org/10.1080/02561751.1940.9676107

—_, 1940b. 'Analysis of a Social Situation in Modern Zululand-B: Social Change in Zululand.' Bantu Studies 14(1): 147-174. doi.org/ 10.1080/02561751.1940.9676112

—_, 1942. 'Some Processes of Social Change Illustrated with Zululand Data.' African Studies 1: 243-260. doi.org/10.1080/ 00020184208706592

Grochain S. and D. Poithily, 2011. 'Sous-Traitance Minière en NouvelleCalédonie: Le Projet Koniambo.' Nouméa: CNRT Nickel, Programme Gouvernance Minière (Document de Travail 4).

Horowitz, L.S., 2009. 'Environmental Violence and Crises of Legitimacy in New Caledonia.' Political Geography 28: 248-258. doi.org/ 10.1016/j.polgeo.2009.07.001 
Merle, I., 2000. 'De l'Idée de Cantonnement à la Constitution des Réserves: La Définition de la Propriété Indigène.' In A. Bensa and I. Leblic (eds), En Pays Kanak: Ethnologie, Linguistique, Archéologie, Histoire de la Nouvelle-Calédonie. Paris: Éditions de la Maison des Sciences de l'Homme (Ethnologie de la France 14). doi.org/10.4000/ books.editionsmsh. 2788

Soriano, E., 2013. La Fin des Indigènes: Le Colonial à l'Épreuve du Politique en Nouvelle-Calédonie. Paris: Karthala. 
This text is taken from Large-scale Mines and Local-level Politics: Between New Caledonia and Papua New Guinea, edited by Colin Filer and Pierre-Yves Le Meur, published 2017 by ANU Press, The Australian National University, Canberra, Australia. 